\title{
Phytopathology
}

\section{The Ebb and Flow of Airborne Pathogens: Monitoring and Use in Disease Management Decisions}

\author{
Walter F. Mahaffee and Rob Stoll
}

First author: U.S. Department of Agriculture-Agricultural Research Service, Horticulture Crops Research Unit, Corvallis, OR 97330; and second author: Department of Mechanical Engineering, University of Utah, Salt Lake City 84112.

Accepted for publication 28 February 2016.

\begin{abstract}
Mahaffee, W. F., and Stoll, R. 2016. The ebb and flow of airborne pathogens: Monitoring and use in disease management decisions. Phytopathology 106:420-431.

Perhaps the earliest form of monitoring the regional spread of plant disease was a group of growers gathering together at the market and discussing what they see in their crops. This type of reporting continues to this day through regional extension blogs, by crop consultants and more formal scouting of sentential plots in the IPM PIPE network (http://www.ipmpipe.org/). As our knowledge of plant disease epidemiology has increased, we have also increased our ability to detect and monitor the presence of pathogens and use this information to make management decisions in commercial production systems. The advent of phylogenetics, next-generation sequencing, and nucleic acid amplification technologies has allowed for development of sensitive and accurate assays for pathogen inoculum detection and quantification. The application of these tools is beginning to change how we manage diseases with airborne inoculum by allowing for the detection of pathogen movement instead of assuming it and by targeting management strategies to the early phases of the epidemic development when there is the greatest opportunity to reduce the rate of disease development. While there are numerous advantages to using data on inoculum presence to aid management decisions, there are limitations in what the data represent that are often unrecognized. In addition, our understanding of where and how to effectively monitor airborne inoculum is limited. There is a strong need to improve our knowledge of the mechanisms that influence inoculum dispersion across scales as particles move from leaf to leaf, and everything in between.
\end{abstract}

Mankind has understood that there is an association between disease epidemics and wind for millennia. Sumerian mythology tells of a demonic god, Pazuzu, that protected people and crops from other wind demons that spread disease on fiery breath (HeeBel 2011). Similarly, the ancient Egyptians thought disease was carried by disease bearing demons that traveled through the air (c. 1570 BCE) (David 2014). Genesis (41:23) mentions grain blighted by the east wind and ancient Indian and Chinese cultures had numerous charms and cures for diseases brought by the wind (Orlob 1973). The Romans considered disease to be associated with wind and prayed to gods to protect their crops (Fowler 1899). Lucretius (c. 54 BCE) in his poem De rerum natura (On the Nature of Things) (Lucretius 1949) states that the wind moved particles into grain crops and caused disease.

Corresponding author: W. F. Mahaffee;

E-mail address: walt.mahaffee@ars.usda.goy

http://dx.doi.org/10.1094/PHYTO-02-16-0060-RVW

This article is in the public domain and not copyrightable. It may be freely reprinted with customary crediting of the source. The American Phytopathological Society, 2016.
We know that Micheli, Leeuwenhoek, Pasteur, and their contemporaries understood that living organisms were airborne (Orlob 1973). Despite this long understanding of the association of disease and wind, there has been limited progress in using this knowledge to make near real-time management decisions. Perhaps the limited management options prior to the age of fungicides created little incentive to use this knowledge.

Modern agriculture is beginning to develop the resources for precision disease management at subfield scales (Baylis 2014; Gil et al. 2014). A key component to creating spatially explicit disease management programs is to understand the actual risk of disease development at the scale of management. This means developing an improved understanding of pathogen dispersion across multiple scales (Fig. 1) and accurate and sensitive methods to assess pathogen presence while predicting where inoculum originated and the probability of deposition and infection. Achieving these advancements requires significant improvement in our ability to rapidly detect and quantify inoculum, coupled with advances in understanding air turbulence at multiple scales (Fig. 2).

Monitoring of pathogen spread at field or regional scales has generally been approached using one of two methods: monitoring for disease presence directly in fields and/or sentential plots or 
sampling for airborne inoculum. Both approaches have numerous limitations; the greatest of which is limited spatial resolution. Hirst (1959) stated that "no trap is likely to detect spores as sensitively as an acre of a susceptible crop in weather favorable to infection." While this statement is technically true because a larger air mass will pass over the field than can be sampled by the sampler, it is also very nuanced by indicating that after deposition there must be favorable conditions for infection and subsequent disease development before scouting can be effective. Scouting efficacy is also affected by the sampling technique, time commitment, and spatial distribution of the diseased plants (Parnell et al. 2015) since examining every plant is not feasible.

For example, consider a 10-ha wheat field with a planting density of 400 plants $/ \mathrm{m}^{2}$ and a 0.01 percent initial plant incidence of wheat rust. The probability of finding a diseased plant using various standard sampling patterns (stratified, $\mathrm{x}$ pattern, and $\mathrm{z}$ pattern) is lower if disease is aggregated compared with randomly distributed (Delp et al. 1986; Gent et al. 2007; Madden and Hughes 1999). It is even lower when disease severity is low (e.g., at the initial stages of the epidemic) and almost nonexistent at the start of the epidemic because there has been little or no spread from the initial infection point. All scouting methods would require an extensive amount of time and probably would not be cost effective. The use of scouting in production agriculture is also further complicated by the rate of epidemic development in relation to the economic threshold for damage. On crops (e.g., apples, cherries, and grapes) where appearance significantly impacts marketability, there is little tolerance for diseased produce; thus the economic threshold is likely below detection limits of typical scouting methods for airborne diseases with rapid rates of development (e.g., powdery mildew). The utility of scouting commercial fields can be even further affected by the field being actively managed using fungicide applications or cultural practices. These practices would likely result in low disease incidence and severity and higher aggregation, thus increasing the number of sampling units that need to be examined (Gent et al. 2007, 2008; Turechek and Mahaffee 2004).

Sentinel plots, unsprayed highly susceptible varieties, are often used to overcome the difficulties of scouting large acreage that is actively managed. However, the assumptions that inoculum will be distributed evenly enough for detection over large geographic areas is not realistic early in epidemics unless the source strength is extremely high (Margosian et al. 2009). There is also the issue of how landscape and terrain heterogeneity and connectivity influence the probability of propagule deposition to the sentential plot or field and therefore, the probability of infection (Meentemeyer et al. 2012; Schmale and Ross 2015). The reliance on disease symptoms limits the timely detection because propagules must have landed on a susceptible host, with environmental conditions suitable for infection and disease development, and enough time must have past (i.e., latent

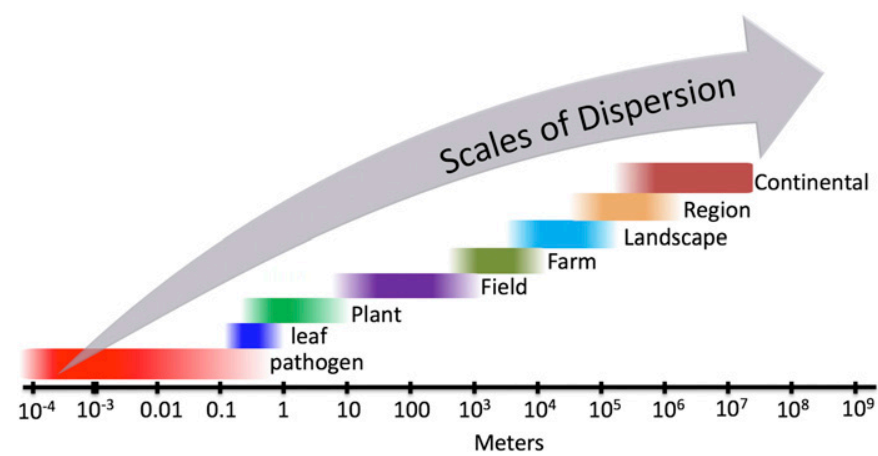

FIGURE 1

Scales of pathogen dispersal. period) for symptoms to be expressed. These limitations have led to the exploration of airborne inoculum monitoring to aid in decision management.

It is not known whether sampling airborne propagules improves the probability of early detection compared with scouting since the air mass sampled is far less than that of a field (e.g., usually less than 100 liters/min). The sensitivity of air sampling is largely a function of proximity to the source of initial inoculum and the air mass that is sampled (Savage et al. 2012). Air sampling is more likely to detect the onset of an epidemic from inoculum sources that are aggregated (mummified fruit under apples, peaches, or blueberries) and situated such that the air sampler can be placed in close proximity to the inoculum source than from inoculum blowing in from another host or field or from inoculum sources randomly distributed throughout a field. This difference is largely due to the dilution that occurs as an inoculum plume moves away from its source (LaMondia and Aylor 2001; Miller et al. 2015; Prussin et al. 2014). Therefore, pathogens that release large numbers of propagules (e.g., Sclerotinia [Rogers et al. 2009]) are more likely to be detected than those that release only a few propagules (e.g., Erysiphe necator cleistothecia [Gadoury et al. 2012]). Despite these limitations, there have been numerous investigators that have pursued the use of spore samplers to aid management decisions.

\section{INOCULUM DETECTION}

Hop downy mildew (Psuedoperonospora humuli) has been managed since the 1960s (Gent et al. 2009; Kremheller and Diercks 1983) using detection of sporangia to initiate fungicide applications. Berger (1969) developed a celery early blight forecasting model that used the hours above $15^{\circ} \mathrm{C}$ and number of Cerospora apii spores sampled to time fungicide application intervals. The fungicide application interval was decreased with increasing quantity of sampled spores. Harrison et al. (1965) found that initial fungicide applications timed to detection of Alternaria solani spores effectively controlled potato early blight while reducing the number of fungicide applications. However, all of these systems rely on microscopic identification of the propagules, which is expensive due to the skill and time required. Microscopic identification is also inaccurate due the difficulties in discerning closely related species with almost identical spore morphologies that are co-located on a surface with a multitude of other overlapping particles under conditions that are less than optimal for maintaining spore morphology (Gregory 1973). There are a multitude of other methods to identify airborne

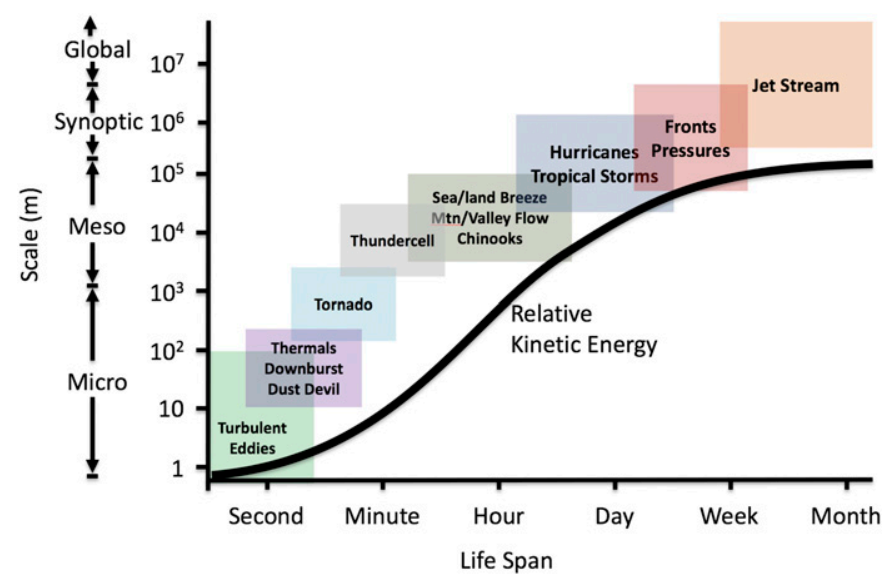

FIGURE 2

Scales of air turbulence (adapted from Laing and Evans 2011). 
propagules including colony growth on selective media (Prussin et al. 2014), lesion development on trap plants (Rieux et al. 2014), and fluorescence (Pan 2015). Each has advantages and disadvantages based on whether they are performed in a lab or in the field, but they are all expensive due to the skill, equipment and time involved. The difficulty and expense of accurately visually assessing sampled propagules has led to a proliferation of methods to detect inoculum at the research, diagnostic, regulatory, and grower level, particularly the use of nucleic acid-based approaches (De Boer and López 2012; Mahaffee 2014; West and Kimber 2015).

Nucleic acid amplification approaches have moved to the forefront of propagule identification, largely due to rapid advances in phylogenetics, next-generation sequencing technology, and approaches to improve the specificity of nucleic acid amplification. The extensive databases of phylogenetically important regions allow for the in silico examination of regions with sufficient heterogeneity to design target specific primers and probes while having enough homogeneity that all or most members of a species are identified. This in silico approach significantly reduces the development time for a new assay. However, even accepting the highly optimistic premise that less than $14 \%$ of the species of the world are known to science (Mora et al. 2011), there is still the need for extensive quality control throughout the assay design process and during its use. One must also remember that the aerobiota can come from anywhere since soil, water, and other particles can be transported long distances by air currents (Aylor 2003; Brown and Hovmøller 2002; Schmale and Ross 2015).

There is a long list of approaches to detect and quantify airborne inoculum based on nucleic acids (reviewed by Capote et al. [2012]). Quantitative PCR (qPCR) and its derivations have become the standard nucleic acid approach for monitoring concentration of airborne inoculum (Carisse et al. 2009b; Fraaije et al. 2005; Klosterman et al. 2014; Rogers et al. 2009; Summers et al. 2015; Thiessen et al. 2016). There are also new isothermal technologies that might soon become just as viable once some of the difficulties are worked out (Mahaffee 2014; Tomlinson 2010; Ward and Harper 2012). The best choice of inoculum detection method will vary based on objectives, the pathosystem, and who will be performing the assay.

The accuracy and sensitivity of nucleic acid based detection and quantification is largely based on the quality of nucleic acids derived from the method of extraction. The optimal method of extraction is highly dependent on the type of propagule being sampled, collection matrix, and what other particles are collected on the collection matrix (Hospodsky et al. 2010). We have observed large differences in lysis of Erysiphales conidia compared with Botrytis cinerea or Magnaporthea oryzae conidia using the same procedure and that the choice of collection matrix influences efficiency of lysis (C. Villari and W. F. Mahaffee, unpublished data). DNA fragment size can also impact efficiency of detection and quantification (Olson and Morrow 2012). Too much shearing has been associated with inhibition of DNA amplification (Demeke and Jenkins 2010) and DNA fragment size and secondary structure can influence reaction efficiency (Tables 1 and 2). Thus, the lysis procedure needs to be carefully examined and tested in order to optimize the overall accuracy and sensitivity of the detection assay. It also needs to be examined in relation to spatial and temporal composition of airborne particles at the sampling location due to the flux in potential inhibitors (Svec et al. 2015). The potential of the extraction method introducing amplification inhibitors into the sample also needs to be considered (Schrader et al. 2012).

Amplification inhibitors are well known (Demeke and Jenkins 2010; Schrader et al. 2012) to effect accuracy and sensitivity of nucleic acid amplification assays and the estimate of airborne propagules (Hospodsky et al. 2010). There are numerous methods to remove inhibitors in general (e.g., flocculation or filtration) or to target specific types (e.g., Chelex to remove metal ions). A combination of approaches to manage inhibitors is usually required and common to many commercial DNA extraction and clean-up kits. The collection matrix can also introduce inhibitors that impact

TABLE 1

Effect of fragment size and inhibitor presence of amplification of target amplicon ${ }^{\text {a }}$

\begin{tabular}{|c|c|c|c|}
\hline DNA fragment size & No inhibitors $\mathrm{Cq}$ & Inhibitors $\mathrm{Cq}^{\mathrm{c}}$ & $\Delta \mathrm{Cq}$ \\
\hline $25.1 \mathrm{~kb}$ & $32.4 \pm 1.8$ & $42.5 \pm 5.0$ & $10.2 \pm 3.6$ \\
\hline \multicolumn{4}{|c|}{$\begin{array}{l}\text { a Unpublished data but see Thiessen et al. (2016) for experimental details. Cq, quantification cycle. } \\
\text { b Fragment created by cloning the NS7-LR5 fragment amplified from Erysiphe necator and cloned into Topo2.1 (Invitrogen) and then cutting with } \\
\text { endonucleases to achieve fragment size. } \\
\text { c Inhibitors consisted of sample rods coated with } 25 \text { mg of vineyard soil. } \\
\text { d Mean of four replications (separate DNA extractions) } \pm \text { standard deviation. }\end{array}$} \\
\hline
\end{tabular}

TABLE 2

Effect of secondary DNA structure on amplification of target amplicon ${ }^{\text {a }}$

\begin{tabular}{lccc}
\hline Fragment & Concentration & Linearized Cq & Plasmid Cq \\
\hline pGPM_NS7-LR5 ${ }^{\mathrm{b}}$ & $10 \mathrm{pg} / \mu \mathrm{l}$ & $18.3 \pm 0.2^{\mathrm{c}}$ & $19.8 \pm 0.5$ \\
& $0.1 \mathrm{pg} / \mu \mathrm{l}$ & $24.1 \pm 0.2$ & $27.3 \pm 0.2$ \\
\hline pIPCEc2-1 $^{\mathrm{d}}$ & $10 \mathrm{pg} / \mu \mathrm{l}$ & $19.0 \pm 0.11$ & $21.4 \pm 0.04$ \\
& $0.1 \mathrm{pg} / \mu \mathrm{l}$ & $27.4 \pm 0.3$ & $29.7 \pm 0.8$ \\
\hline a Unpublished data but see Thiessen et al. (2016) for experimental details. Cq, quantification cycle. & \\
b Fragment created by cloning the NS7-LR5 fragment amplified from Erysiphe necator and cloned into Topo2.1 (Invitrogen) and linearized by \\
cutting with EcoRI.
\end{tabular}


efficiency. Klosterman et al. (2014) found that silicon vacuum grease coated sampling rods inhibited the qPCR despite using isopropanol to clean the rods. Thiessen et al. (2016) used a more extensive cleaning protocol to remove different oils, minerals and other inhibitors associated with different rod vendors since the inhibition was not associated with the silicon vacuum grease but did occur with Vaseline, lecithin, and honey (A. Peetz and W. F. Mahaffee, unpublished data). The amount of inhibitors accumulated during the sampling period by the collection matrix can also affect DNA extraction or PCR efficiency (Gent et al. 2009). A 1:10 dilution of the extraction eliminated the inhibition without reducing sensitivity; however, they were still not able to detect less than 100 P. humuli sporangia reliably. We have found that inhibitors affecting the qPCR are in constant flux and highly dependent on the sampler location and time of year, with pollen load, pesticide applications, spider webs and insects being most often associated with inhibited reactions when quantifying E. necator spores using qPCR and LAMP assays (L. Thiessen and W. F. Mahaffee, unpublished data). Inhibitors also have a greater impact when the target is near the detection limits. These results dictate that polymerases and master mixes designed to work in the presence of inhibitors (Chen and Romesberg 2014; Minogue et al. 2014) must be used since most nucleic acid extraction techniques do not adequately remove all inhibitors (Schrader et al. 2012). They also indicate that nucleic acid concentration derived from environmental samples is not going to translate to dilutions from the lab; thus regression curves relating quantification cycle $(\mathrm{Cq})$ to inoculum quantity need to address many of the above issues.

The most common means of determining the sensitivity of an assay is to extract DNA from a known large number of propagules and dilute until detection no longer occurs (Bilodeau et al. 2007). While this information is useful in understanding the theoretical limits of detection, it is not an accurate representation of the number of propagules sampled. The approach by-passes numerous experimental errors that affect the efficiency of DNA extraction and amplification (Svec et al. 2015). There is often an increase in the $\mathrm{Cq}$ and variance between diluted DNA and extraction of conidia which can result in an order of magnitude over estimate using standard curves based on diluted DNA (Fig. 3). These results indicate that detection limits and quantification limits have to be considered as independent traits of the assay since detection was still accurate but quantification at low spore concentrations was not. Similar phenomenon have been observed by others (Nicholson et al. 1998; Rogers et al. 2009); however, Carisse et al. (2009b) did not see an effect when they diluted the target DNA in water containing $10 \mathrm{ng} / \mu \mathrm{l}$ salmon sperm DNA. The addition of exogenous DNA to reactions could have accounted for the potential effects on nontarget DNA on the kinetics of the qPCR (Bar et al. 2012), thus resulting in a more accurate correlation. It is more likely, though, that the lack of differential response was the due to dilution of inhibitors when the spore suspension was extracted and diluted. There can also be a difference in extraction efficiency of spores placed on rods compared with spores placed directly in a lysis matrix, particularly near detection limits, that can affect propagule estimates (Falacy et al. 2007).

In addition to inhibitor removal during nucleic acid extraction, there are methods that can be employed to assess the effect inhibitors are having on amplification and detection. They generally fall into two approaches: amplification of exogenous or endogenous controls (Bar et al. 2012). Exogenous controls can be added before or after DNA extraction with the former being unable to distinguish between PCR inhibition or losses during the extraction process. These reactions can be multiplexed with the target reaction, but competition for reagents could interfere with the amplification efficiency of either or both targets (Bar et al. 2012; Gevertz et al. 2005). We have found that multiplexing with exogenous controls, whether they employ competitive primers or not, tends to reduce the sensitivity of the assay, particularly in the presence of inhibitors or extremely high background of nontarget DNA (W. F. Mahaffee, unpublished data). Our experience also indicates that the quantity of amplification controls need to be near the assay detection limits in order to accurately represent the potential for inhibition due to the errors in estimating inoculum concentration. There are also mathematical approaches that utilize reaction kinetics to detect inhibition (Bar et al. 2012).

\section{INOCULUM COLLECTION}

Methods for collecting airborne inoculum can be divided into passive or active sampling [Reviewed by (Jackson and Bayliss 2011; West and Kimber 2015)]. Passive methodologies are dependent on gravity or inertia to deposit propagules onto a surface. This surface can take many forms from a plant, leaf, petri plates, funnel, or coated artificial substrate (Gregory 1973). Passive samplers are usually very inexpensive but extremely variable in the air mass that they sample because collection efficiency is dependent on the velocity of the air mass moving over the surface and its orientation to the direction of air movement (McCartney et al. 1997). Collection surfaces have been mounted on or in wind vanes (von Qualen and Yang 2006) in attempts to keep the collection surface oriented to the wind, but a vertical collection surface has little ability to represent the gravimetric settling that occurs during stable atmospheric conditions prevalent at night and any shielding could further reduce collection efficiency by decreasing the air mass that moves over the surface due to the friction and turbulence created by the shielding (Gregory 1973). This reduction is particularly true for the use of petri plates; as the distance between the sampling surface and the top of the petri plate wall increases so does the turbulence and strength of the boundary layer over the plate, which significantly reduces the collection efficacy with increasing speed of the air mass moving over it (Gregory and Stedman 1953). One could argue that passive samplers are, on average, comparable within a field over the same time period or that they are a relative measure of deposition. However, what they represent will depend on spatial variability of turbulence within the study area, which will make comparison among fields far more difficult. Passive

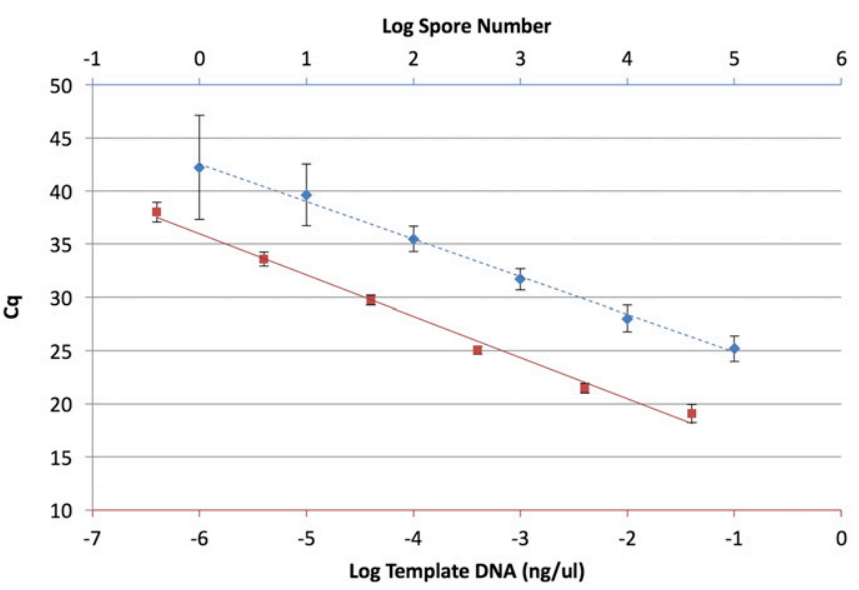

\section{FIGURE 3}

A standard curve comparing dilution of purified DNA with extractions of spores on rods. Square, Erysiphe necator DNA (lower $x$-axis) $y=$ $-3.87 x+12.73, R^{2}=0.992$; diamond, spore extractions of $1,10,100$, $1,000,10,000$, and 100,000 spores placed on vacuum grease-coated, stainless steel rods (upper $x$-axis) $y=-3.53 x+42.55, R^{2}=0.996$. Lower limit of both curves equivalent to 1 spore or 50 copies of the internal transcribed spacer region. Mahaffee (unpublished data). 
samplers are not useful for quantitative assessment in time without the colocation of weather monitoring equipment to determine the quantity of air sampled and considerable post-collection analyses. Their strength is that their low cost and lack of a power requirement allows for a high density of samplers to be placed throughout a field or region, which is useful for monitoring presence or absence of inoculum. However, the probability of detecting inoculum is still dependent on the source strength and the subsequent dilution of the inoculum plume across a field or region (Miller et al. 2015; Prussin et al. 2014; Schmale and Ross 2015). The large collection surface size of most passive samplers also makes it difficult to process for nucleic acid extraction and post-collection processing increases the probability of introducing contamination and possible DNA degradation, both of which reduce detection limits.

Active (volumetric) samplers employ some mechanical means to impinge particles onto or into a collection matrix and sample a consistent air volume. Often these samplers are further subdivided into types based on the method they use to create inertia or how they impinge the propagules (e.g., impaction, filtration, or cyclonic/ centrifugal separation). However, they are all based on the premise that the inertia of a particle will cause the particle to impinge onto or into the collection matrix. Samplers can be stationary or mobile.

Impaction devices move a collection surface through an air mass at a known velocity and impinge particles onto a collection surface (Chandelier et al. 2014; Noll 1970; Thiessen et al. 2016); thus, sampling a known air volume. They are often chosen over other active samplers because they are less expensive, smaller, and require less energy to operate. However, they have several limitations that need to be considered. The efficiency of the particle size captured is dependent on the speed and aerodynamics of the collection surface (Gregory 1973). The Rotorod sampler, with the 1.5-mm-wide square rod, is most efficient at collecting large particles $(>15 \mu \mathrm{m}$ in diameter) with more inertia than smaller propagules (Noll 1970). This limitation narrows the utility of these samplers for some pathosystems, especially those that produce small spores, unless the speed of rotation can be altered (e.g., lengthen sampling arm) to more efficiently collect smaller particles. There is also the issue that the collection surface can be rapidly overloaded in dusty environments, which has led some to use intermittent sampling times (Carisse et al. 2005). Noncontinuous sampling might miss particle plumes since canopy escape is likely to be highly intermittent based on prevailing wind and microenvironment (Savage et al. 2010). Collection surface overload might not occur for particles that are naturally sticky. We found that the collection of $E$. necator conidia were identical on stainless steel rods coated with vacuum grease with or without the addition of $25 \mathrm{mg}$ of soil. We have also observed that circular sample rods will rotate in the sample arm, due to the increase in mass on the leading edge, resulting in the entire rod becoming coated with collected particles (Thiessen et al. 2016). The collection surface is constantly exposed to the environment so rotation during arid conditions can cause desiccation or precipitation or irrigation events could wash off sampled particles. All of these issues could significantly reduce the detection limits. Over the past 5 years we have observed that during the dry summer months, the quantified inoculum load from daily sampling of spores is often greater than the biweekly sampling. It is not clear whether this reduction is due to heat, desiccation, or increase in the pollen collected of some species. However, we have not noticed a difference during precipitation events (W. F. Mahaffee, unpublished data). All of these results indicate that caution must be used in interpreting any results of propagule concentration and a combination of approaches to estimate inoculum presence and concentration might be needed. Furthermore, the sampling frequency should be within the latent period of its target pathosystem under optimal conditions in order to add some measure of safety against false negatives.
Suction type samplers [Reviewed by (Jackson and Bayliss 2011; West and Kimber 2015)] can be further divided into silt, cascade, filter, vortex samplers, or combinations thereof based on how they create the inertia needed to impinge particles onto the collection surface (solid or liquid). Silt based samplers (e.g., Burkard, Air-OCell) cause impaction by accelerating and turning air just before a collection surface, which causes entrained particles to impinge onto the collection surface. Cascade samplers employ similar physics but use multiple stages to separate particles into size classes. Filter samplers pull the air through a porous matrix (solid or liquid) that impinges the particles. The collected particles block the pores over time and cause the sample volume and efficiency to change (Jackson and Bayliss 2011). All of these samplers typically employ a large collection surface that makes processing for nucleic acid extraction more difficult and may reduce sensitivity because of the dilution that occurs during extraction. Another type of suction sampler generates an air vortex that causes the particles to be centrifugally deposited on vessel walls, a liquid film along the wall (e.g., Biogaurdian), or onto the bottom of a sampling vessel. Electrostatic charge is another method used to remove particles from the airstream drawn into samplers. While we found them rather good for collection of E. necator conidia, there were issues with electrical arcing during periods of low humidity that destroyed samples. The collection efficiency of many suction samplers is highly dependent on the orientation of the intake orifice to wind direction; thus, many are integrated with or mounted on a wind vane or have a $360^{\circ}$ collection orifice. Suction samplers also tend to be larger and this significantly increases their chance of "tractor blight" and difficulty in placing the sampler within the row or above the canopy. Suction samplers differ significantly in the sampling volume, efficiency, and energy requirements (West and Kimber 2015), but their expense is the largest barrier to their use in routine monitoring. Regardless of the sampler type, the area that the sampler represents is directly proportional to the height above the ground (Seinfeld and Pandis 2006); thus, the optimal sampling height will depend on the expected inoculum source is localized near the sampler versus long-distance spread (e.g., subfield versus regional scales) (described under Pathogen Dispersion).

To date, the majority of approaches to mounting spore samplers to mobile platforms have employed impaction surfaces (e.g., petri plates with agar or coated with vacuum grease) attached to an unmanned aerial vehicle (UAV) as a more cost effective means of tracking spores long distances than manned flights (Hirst et al. 1967). They can be considered active samplers since the movement of the transport vehicle moves the air mass over them and GPS can be used to track airspeed and direction (Schmale et al. 2008). The air volume sampled and efficiency is dependent on the speed of the vehicle and the sampler's orientation to air mass movement. They are also then subject to differences in sampling efficiency due to the turbulence created by the structure of the UAV (MaldonadoRamirez et al. 2005; Schmale et al. 2008). Active samplers have also been added to small UAVs (Eninger and Johnson 2015). Using a simulation approach, Savage et al. (2012) demonstrated that there was a greater probability of detecting a pathogen using mobile samplers, capable of a $10 \mathrm{~h}$ flight, than passive vertical samplers in a wind vane-like device. Detection using either device was still highly variable and the probability of detection deceased with reduction in source strength for both devices. Whether these results hold true in field settings needs to be investigated, particularly comparing mobile and stationary active samplers. In preliminary experiments, we had little success with mounting rotating impaction samplers onto ATVs driven through fields or mounting samplers on RC helicopters flown over vineyards or hop yards. Detection was more likely if the canopy was first disturbed by the wake of the vehicle (e.g., drive or fly down a row and then turn around and travel the same path). However, we were successful in collecting 
E. necator conidia using cellophane tape on the RC helicopter prop blades. We also were able to detect E. necator from vacuum grease coated quadcopter and $\mathrm{RC}$ airplane propellers that were flown over vineyards, although, there were losses due to rotational forces of the propeller and difficulty in removing collected particles from the propellers. Both the copter and quadcopter had higher numbers ( $>300$ spores) than the plane (only just above detection limits), likely because they could disturb the canopy with their prop-wash, causing conidia to escape the canopy, and continue to hover over the disturbed canopy. Again, these results indicate that understanding when dispersion occurs is critical to improving methods for detection and quantification of airborne inoculum. It is now possible for UAVs to conduct autonomous (Schmale et al. 2008) search patterns over large fields. However, sampling will still need to occur during dissemination events which would require UAVs with either long endurance or a rapid deployment during predicted dissemination events to enhance the probability of detecting field inoculum sources. Because of limited flight times, quadcopters are likely to be more useful for the local source, perhaps directed by remote spectral data, while planes would be better for detecting longer distance inoculum sources. There is also the potential for using tethered or untethered balloons to monitor longer distance spread (Bryan et al. 2014).

\section{PATHOGEN DISPERSION}

The topic of pathogen dispersion is confused by how the terms dispersal and dissemination are used in the different disciplines that study particle movement. The meteorological and engineering communities consider dispersion to be the processes that occur while the particle is airborne and dissemination to be the entire process represented in Figure 4 . The biological community often uses them interchangeably but defines dispersal as the movement of individuals from birthplace to breeding site (e.g., dispersion kernel measures distance of disease spread). Throughout this review we have used the biological meanings of dispersion and dissemination.

Dispersion kernels are a probability density function of dispersal distance (Chesson and Lee 2005) and usually derived by quantifying disease incidence or severity at distances from a focal source over time. Thus, they are usually averages of more than one dissemination event and only represent spread under similar environmental conditions (e.g., a connected homogeneous host population in a similar environment). They are not based on a mechanistic understanding of pathogen transport and likely are not scalable across complex terrain with spatially heterogeneous and discontinuous host populations for real-time decision making (Meentemeyer et al. 2012). In order to truly be able to predict disease spread we have to get at the underlying mechanisms and learn how to scale them. This involves developing multidisciplinary teams that bring together expertise from physics, biology, computer science, and engineering.

Pathogen dispersion consists of four components (Fig. 4), only one of which has been well studied, inoculum production. This is largely because it is rather easy to experimentally isolate the environmental factors that influence inoculum production.

Inoculum production. Dispersion starts with the development of pathogen structures capable of producing viable inoculum. The precise details of this process are dependent on the biological and environmental factors that determine the fecundity of a pathogen. While pathogens can vary in specific response, the rate of inoculum production is typically a function of some combination of humidity, radiation exposure, temperature, and host response (Dahlberg and Vanetten 1982).

Inoculum production is largely a subleaf scale process that is usually assessed at the plant or leaf scale and modeled as an average across all plant tissues at the subfield or higher scale (Ferrandino 2012; Meredith 1973). While this approach has utility in understanding

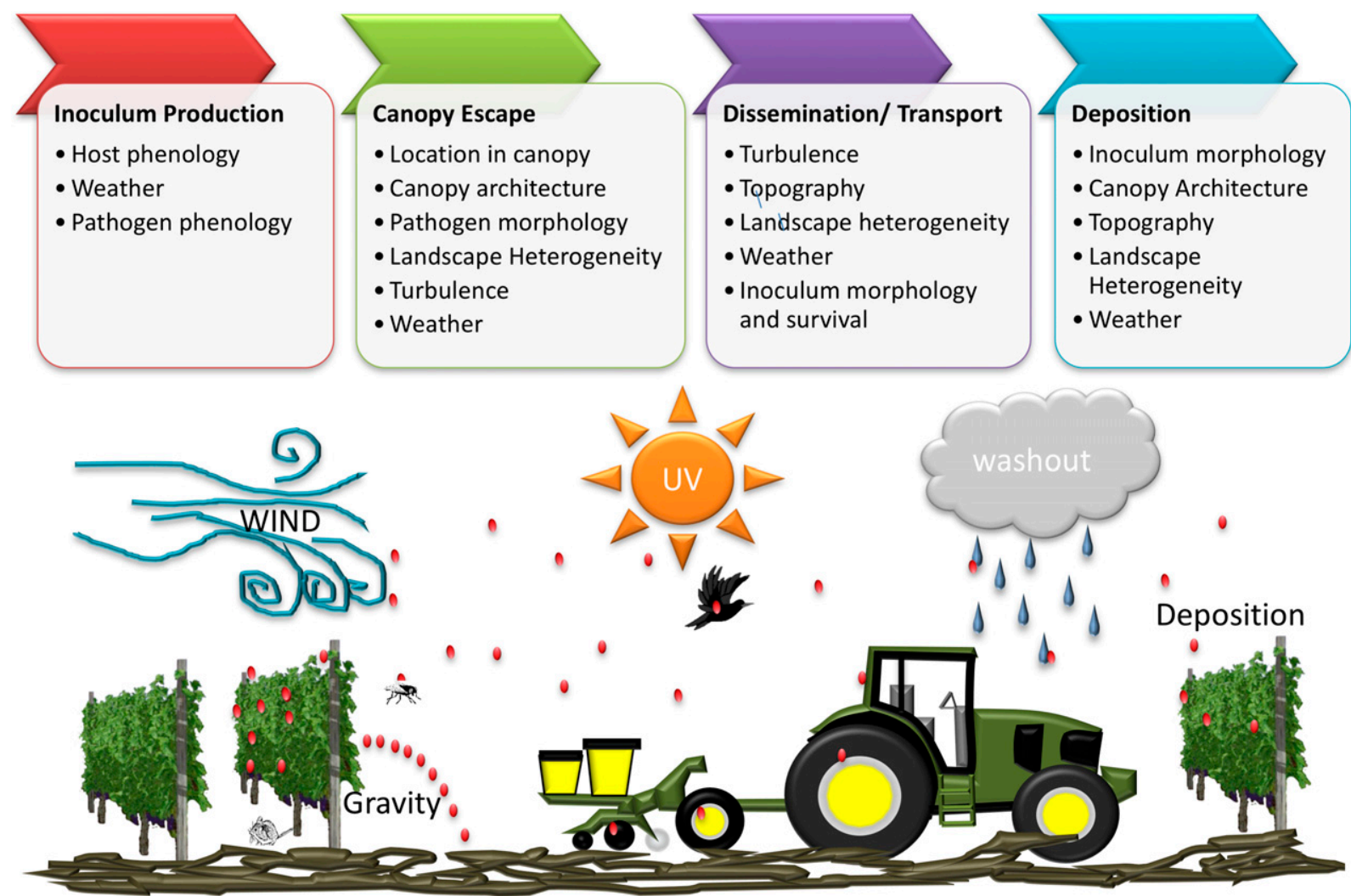

FIGURE 4

Components of inoculum dispersion and factors that impact the different components. 
disease development over time at the field or higher scale, it is not an accurate prediction of real-time risk at a subfield scale. The approach fails to incorporate how microclimate and leaf phenology influence pathogen growth and reproduction. For example, the growth and sporulation of the Erysiphales are highly influenced by the interactions among solar radiation, temperature, and humidity (Glawe 2008), which are impacted by canopy architecture and leaf phenology (Bailey et al. 2014a, 2016). Host photosynthesis increases with increasing sunlight (to a maximum), which results in increased nutrient availability to the pathogen. Increased photosynthesis and leaf temperature leads to increased respiration and ultimately results in higher relative humidity and lower temperatures within the leaf boundary layer (Ferro and Southwick 1984). The sum of these factors likely enhances pathogen growth and/or sporulation and increases the rate of disease development. However, increased exposure to solar radiation (Bailey et al. 2014a, 2016) could lead to stomatal closure and subsequent lower relative humidity within the boundary layer, removing the buffer from extreme leaf surface temperatures; thus, decreasing germination, infection, or sporulation (Austin and Wilcox 2012; Carroll and Wilcox 2003). High temperatures can also cause alterations in the host physiology that result in reduced susceptibility and infection (Mahaffee et al. 2003; Peetz et al. 2009). Host maturity or source sink relationships are also factors that influence host resistance to disease development (Merry et al. 2013). It is this complex interaction of environmental parameters with the pathogen and host that ultimately affect the rate of sporulation and subsequent disease spread locally or long distance (Mundt 2009). As such, being able to model the subplant scale processes is important to developing mechanistic models for real-time disease risk.

The development of these fine scale mechanistic models is dependent on the continued maturation of remote sensing techniques that are capable of estimating leaf parameters at scales ranging from subleaf to plant scales (e.g., thermal cameras [Bailey et al. 2014a; Zarco-Tejada et al. 2012]). This will be especially powerful when paired with a technique such as Terrestrial LiDAR that enables the mapping of plant architecture over a similar range of scales (Dial et al. 2011; Sanz-Cortiella et al. 2011).

While our ability to measure leaf temperature and canopy architecture using remote sensing techniques have both advanced, leaf level surface moisture and relative humidity measurements have not. Making advancements in the capability to measure these variables from leaf to canopy scales remains a challenge. Recent advances in canopy microclimate modeling are starting to address this issue. Advancements include models that can resolve solar radiation incident on individual leaves and comprehensive models that fully simulate the details of energy and moisture at subplant scales (Bailey et al. 2016; Sinoquet et al. 2001) on collections of leaves. These new models can provide subplant information on the distribution of leaf surface temperature, relative humidity, and radiation, therefore, offering a path forward toward accurately predicting the strength and distribution of inoculum production and its association with canopy microclimate and architecture.

Canopy escape. Once propagules are available for dispersion, dissemination starts when they are actively or passively released from sporophore (Isard et al. 2005). These releases are typically triggered by moisture and vapor pressure deficit and are thought to play a role in helping spores escape the thin local layer of air (boundary layer) that directly interacts with the infected plant component (Meredith 1973).

Passive release of spores is common with many fungal plant pathogens of importance to agricultural and natural systems (e.g., powdery mildews and rusts). Traditionally, passive release is described as occurring when the wind speed impinging on an infected leaf surface exceeds some threshold resulting in forces on a spore that exceed the adhesion force between a spore and its sporophore (Aylor 1990; Davis et al. 1997; Willocquet et al. 1998). The precise wind speed requirement for release is considered to be highly variable between different pathogens. Even for a particular pathogen, the exact wind speed value that initiates release and the total number of spores released from a colony at a given wind speed have been found to vary significantly. Interestingly, the wind speeds found to initiate release are quite large $(\sim 3 \mathrm{~m} / \mathrm{s})$ compared with typical mean wind speeds measured in real plant canopies (Miller et al. 2015; Pan et al. 2015). This is compounded by the observation that the force required to separate a spore from its sporophore (Aylor 1975), assuming the sporophore behaves as purely elastic materials, is larger than the mean velocities typically measured within canopies. As a result of the apparent contradiction, researchers have hypothesized that other factors including leaf flutter, mechanical "tapping", and unsteady canopy winds must play a factor in passive spore release (Davis et al. 1997; Willocquet et al. 1998). As yet, no study has quantified the correlation between the level of turbulence and its characteristics (e.g., turbulence intensity, leaf level wind shear, or leaf level wind accelerations) and the release of spores.

Dissemination. Once spores exit the leaf boundary layer, they will either be deposited in the immediate vicinity of the infection site, or they will escape the plant canopy and become available for transport (Isard and Chamecki 2016; Mundt 2009). The observed dispersive behavior of epidemics (Ferrandino 1993; Mundt et al. 2009a) indicates that sufficient number of propagules must escape the plant canopy and be dispersed. Their escape from plant canopies is highly modulated by the architecture of the particular plant canopy of interest (Bailey et al. 2014b; van Hout et al. 2007). In general, escape is considered to be a function of canopy density, release height, and atmospheric stability (Bailey and Stoll 2013, 2016; Bailey et al. 2014b; Chamecki 2013; Prussin et al. 2015). Localized transport can be defined as movement through the air within distances that are on the order of the source distance from the ground and or the height of the plant canopy of interest. At these distances, transport is strongly dependent on the canopy and inoculum source characteristics and can be non-Gaussian in nature (Bailey et al. 2014a; Miller et al. 2015; Reynolds 2012). Bailey et al. (2014a) demonstrated that the heterogeneity of trellised canopies decreases the amount of time it takes for a particle to escape the canopy and therefore, increases the likelihood of long distance transport. Furthermore, Miller et al. (2015) used surrogate particles to show that particle movement is channeled down the rows but skewed toward the mean wind direction, which explains elongated disease foci and clonal aggregation observed in trellised canopies (Brewer et al. 2012). Long distance transport can be categorized as all transport at larger distances. Presumably long distance transport is more amenable to models based on assumptions of Gaussian spread (Isard and Chamecki 2016; Seinfeld and Pandis 2006). Since propagule movement in an air mass is likely similar to that of other airborne particles with a similar settling velocity, studies of pollen transport (Jarosz et al. 2003; van Hout et al. 2007), dust and sand transport (Pardyjak et al. 2008), and general particulate matter transport (Holmes et al. 2009) can be used to help improve and develop models for pathogen dispersion.

Deposition. Ultimately, for a pathogen to propagate, propagules must be deposited from the air onto susceptible host tissue (Aylor 2003). There are two primary mechanisms of deposition, wet deposition and dry deposition. Wet deposition occurs by two processes. The first occurs during the formation of rain droplets. Propagules of numerous airborne microorganisms can serve as catalyst for water condensation or ice nucleation, thus becoming incorporated into raindrops and potentially deposited during rain events (Huffman et al. 2013; Morris et al. 2013). Airborne propagules can also be "scrubbed" from the atmosphere by direct interception from rain drops (Aylor and Sutton 1992; 
Seinfeld and Pandis 2006) and deposition due to "scrubbing is considered to be largely dependent on rainfall intensity and type (Aylor 1989). Depending on the regional climate and the dependence of the pathogen's reproductive cycle on moisture, wet deposition may or may not be important on average (Prussin et al. 2014) but it should be expected to play an important role for some pathogens after specific weather events (Sutton and Jones 1979).

Dry deposition is the result of a combination of gravitational settling and particle impaction (Aylor and Flesch 2001; Raupach 2001). Deposition by gravitational settling is the process by which particles are deposited on a horizontal surface purely by gravity. It is largely a function of a spore's settling velocity, which is determined by the aerodynamic diameter and density of the propagule (Seinfeld and Pandis 2006). Inertial impaction happens when the inertia imparted by the air on a propagule is great enough to overcome local streamline displacements caused by the leaf (or other plant deposition surface). For an individual propagule, this process is modeled as a function of the Stokes number, which is the ratio of the timescale for a spore to adjust to a change in the flow field to the timescale of the flow field to adjust to the leaf. Based on wind tunnel studies using laminar flows and numerical simulations (Marple and Liu 1974; May and Clifford 1967), the low Stokes number typical of spores and other pathogen propagules indicate that the propagules are unlikely to deposit on a plant. However, Moran et al. (2013) demonstrated that turbulent fluctuations enhance deposition and that using the average wind speed in Stokes number calculations is incorrect for glass slides (Fig. 5). Their results were confirmed for leaves and blades of grass (Fig. 5) (T. Price, R. Stoll, J. Vernanth, and E. Pardyjak, unpublished data), which indicates that more work is needed to determine the impact of plant architecture at the plant to subleaf scales across a full range of Stokes numbers, especially for low speed flows typically found within plant canopies.

\section{APPROACHES TO STUDY PATHOGEN DISPERSAL}

Ideally, dispersal should be measured by determining the distance a propagule travels from source to deposition site since an airborne propagule must land on a susceptible host to complete the dispersal process. However, in practice, deposition is extremely difficult to measure unless one measures effective deposition (i.e., disease). The exponential dilution of the propagule plume with distance from the source (Miller et al. 2015; Mundt et al. 2009a; Sackett and Mundt 2005) makes it rather difficult to locate or detect propagules more than few centimeters from one or few lesions on a plant unless massive amounts of inoculum are released. To scale the problem, trying to find a car that left Denver, CO somewhere along the West Coast of the United States would be like trying to locate an E. necator conidium $2 \mathrm{~m}$ away on the adjacent row.

Researchers have employed numerous approaches in attempts to determine the spatial and temporal movement of inoculum plumes away from their source. The most common approach is to inoculate some proportion of the plants in a field (Mundt et al. 2009b; Prussin et al. 2014; Rieux et al. 2014), often with a specific pathogen genotype, so it is possible to limit the potential inoculum source to the inoculated plants. The main limitation of this approach is that the inoculum release cannot be experimentally controlled to a given sampling period. Thus, it is never clear whether the sampled propagules originated from the current conditions. It can also be difficult to have sufficient source strength to detect dispersion events more than a few meters from a plant, which usually means the scale of the source has to be above the plant scale. This makes elucidating the mechanism of escape, dissemination, and deposition more difficult. As an alternative, a number of surrogate particles (e.g., Lycopodhium spp. spores [Aylor et al. 2011; Pan et al. 2015] or microspheres [Bouvet et al. 2006; Miller et al.
2015]) and methods of marking them have been employed to accurately delineate when particles were released. While these surrogates are useful to associate particle dissemination with particular time frames of air turbulence, they employ particles that may or may not behave similar to fungal spores and can only examine factors influencing particle dissemination and deposition. The particles often differ in specific gravity and are spherical in shape which could increase their terminal velocity and reduce turbulent transport. There is also the issue of releasing the particles without imparting velocity or a trajectory that would be different from particles escaping a leaf. Each approach has its advantages and disadvantages that have to be taken into account when interpreting the results. A combination of approaches would likely be the most informative.

A missing aspect in these studies is information on long distance dissemination. High quality experimental studies of long distance pathogen dissemination with meteorological data at time scales sufficient to resolve turbulence are rare. Some studies exist for dense homogeneous canopies (Ferrandino and Aylor 1987; Prussin et al. 2015; Sackett and Mundt 2005) but we know of no studies of perennial crops. Furthermore, no studies exist that include measurements of both crosswind and vertical gradients in spore concentration. This limits our ability to validate models (including those that are widely used [Draxler and Hess 1997]) and develop new dissemination theories, especially within heterogeneous canopies.

\section{USE IN DISEASE MANAGEMENT}

With the advent of molecular tools for detecting and quantifying microbial propagules, there has been a renewed interest in monitoring dispersion of airborne plant pathogens and using this data to inform management decisions. While there are numerous advantages to using data on inoculum presence to aid management decisions, there are limitations in what the data represents that are often unrecognized.

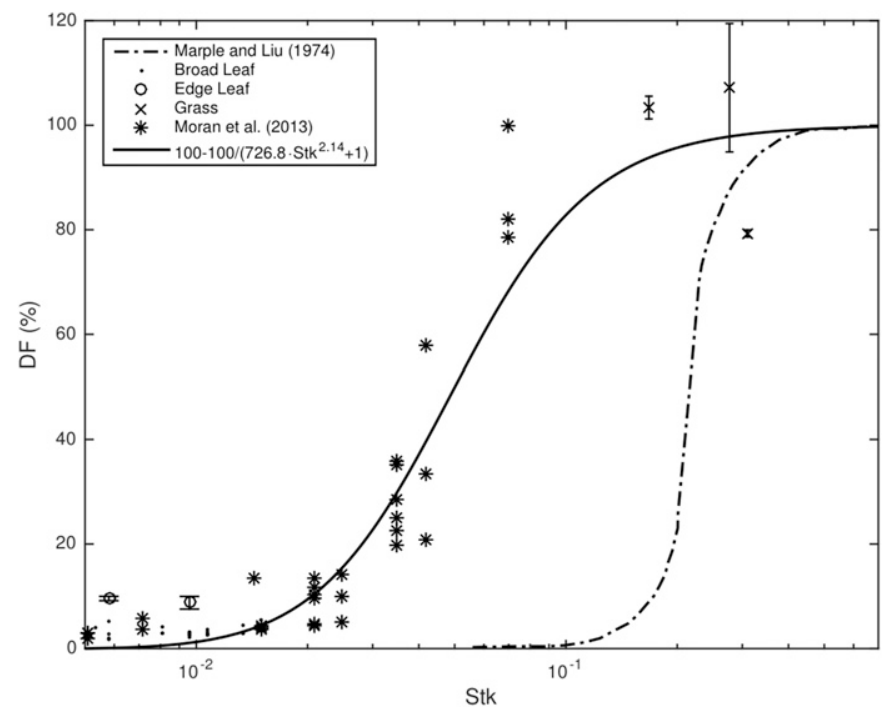

FIGURE 5

Deposition fraction (DF) as a function of Stokes number for microscope slides and representative plant components measured in a wind tunnel in an isotropic turbulent flow. Vertical error bars indicate one standard deviation for cases with variable wind facing deposition surfaces (i.e., broad leaf case) and DF values greater than $100 \%$ are a result of deposition onto nonwind facing surfaces. The dot-dashed line indicates the classical deposition model of Marple and Liu (1974) developed based on laminar flow experiments, and the solid line indicates the curve fit from Moran et al. (2013). 
The area represented by a sampler of any type will be extremely dynamic over time due to how the air mass moves over the field terrain (Schmale and Ross 2015), canopy heterogeneity, and the resulting influences on plant scale turbulence (Bailey and Stoll 2013; Bailey et al. 2014b; Miller et al. 2015). Thus, evaluation of whether inoculum detection or quantification can be used as a decision aide or to estimate disease levels should be examined at the management scale it will be employed. There is a high potential for plot-to-plot interference with inoculum concentrations derived within a small plot, which means that replications need to be spatially separated by sufficient distances such that source strength from one plot does not impact another plot. This spatial separation will increase variability resulting from the use of multiple field locations under different management practices (Thiessen et al. 2016); however, it is critical for accurate assessment of disease management based on site-specific inoculum quantity.

Placement of a sampler is largely an educated guess that can be informed by the biology of the pathosystem being monitored and its spatial and temporal distribution. If inoculum presence or quantity data will be used to make management decisions, then the size of a management unit (e.g., what is the smallest area they will treat), the threshold for economic loss, and grower tolerance for risk also have to be considered. These parameters figure into determining at what scale (Fig. 1) the monitoring has to occur and what type and number of sampling devices are needed. Monitoring will usually need to occur at a scale lower than the management unit. For a pathogen like $E$. necator, is it relatively easy to locate the most probable site of overwintering (Thiessen et al. 2016) to a group of vines where cleistothecia are most likely to overwinter in the grape bark (Gadoury et al. 2012). The sampler placement is at the plant scale in locations where the disease from the previous year was the most severe (Mahaffee 2014). This location appears to be useful for field scale management (Thiessen et al. 2016). If there is a high degree of uncertainty of where the pathogen may overwinter and there is low frequency of overwintering locations, such as with P. humuli (Gent et al. 2009; Summers et al. 2015), then placing samplers at single locations may be problematic. However, when overwintering is randomly distributed throughout a field, precise sampler location might be of less importance (Van der Heyden et al. 2014). When overwintering of a pathogen is not thought to occur within a region (e.g., cucumber downy mildew [Ojiambo et al. 2015]), sampler placement becomes a lot more difficult to predict, but should be placed well above canopy height to increase the area of the field it represents. Pathogen movement into a region will likely be very stochastic and associated with major wind events (Schmale and Ross 2015) or transport of diseased plant materials (e.g., P. infestans outbreak 2008 [Scherm et al. 2014]). Placement on top of buildings may increase the probability of detecting long distance movement but the turbulence caused by the building and roof top structures could significantly change the air mass that is being sampled and lead to false conclusions (Banks and Meroney 2001; Banks et al. 2000; Wilson 1979).

Monitoring above the field scale for actionable data at the field scale is problematic for pathogens that reproduce rapidly under a wide range of conditions. It might be more acceptable for pathogens that have very discrete infection periods that are somewhat infrequent and have a strong source strength from their point of origin (Meentemeyer et al. 2012). However, the laws of probability are not favorable for inoculum capture and detection. If we assume that we are only concerned with what is in the air mass that spans the volume over of a 1 ha plant canopy to $10 \mathrm{~m}$ above it, there is $10^{10}$ liters of air under still conditions. Even with a million spores evenly distributed in this volume the probability of sampling a detectable number of spores is very low when we are only sampling 10 to 1,000 liters/min, depending on the sampling device. Once the wind starts moving this air mass, the probability of sampling an individual spore exponentially decreases.
Many reports demonstrate a correlation of airborne inoculum to disease severity or incidence (Carisse et al. 2005, 2008) and there is conflicting evidence as to whether there is an association (Rogers et al. 2009). However, one should not expect a clear association between airborne inoculum and disease severity with most pathosystems. Inoculum available for dispersion is going to be environmentally driven and likely to fluctuate from day to day and within the timespan of one day (Gent et al. 2009; Luo et al. 2007; Rogers et al. 2009), though once disease is present at a location it generally does not disappear, unless you consider leaf abscission or other loss of infected tissue. There are significant correlations of cumulative airborne inoculum quantity over a season to plant disease (Carisse et al. 2009a), but it is not clear that this relationship is predictive of disease levels across regions.

\section{WHERE ARE WE GOING?}

With the rapidly increasing economy of computational power and robotic systems as well as our emerging ability to biophysically model increasingly complex systems, we are rapidly moving toward the ability to monitor and predict the real-time risk being faced by growers. We envision a scalable biophysical modeling environment that predicts the real-time risk at fine spatial and temporal scales. The system will employ artificial intelligence that is informed by the data derived from autonomous sensor arrays, to adapt to each site and reduce uncertainties associated with predictions. Such a system will initially allow management practices to be targeted to individual plants in high value productions systems like wine grapes, tree fruit and small planting areas (e.g., $<10 \mathrm{~m}^{2}$ ). Real-time disease risk will be based on the specific microclimate, plant phenology, and pathogen development allowing the grower to decide their risk tolerance.

Barriers to reaching this vision include: (i) cost of computation in terms of dollars and time, but these continue to follow Moore's law (Mack 2011) and are rapidly increasing in power with decreasing costs; (ii) the continued improvement and reduction in cost of autonomous vehicles; and (iii) development of point of collection detection and quantification technology that is robust enough for harsh field environments as well as rapid and cost effective enough for the scale at which decisions are made. The latter is not going to be easy and there are numerous approaches for achieving this goal (Jung et al. 2015; Lafleur et al. 2016; Su et al. 2015). However, they are still challenged by the problems associated with sample processing, which include removal of inhibitors and detection of rare targets. There will need to be significant advances in collection and sample-processing technology in order to incorporate inoculum monitoring based on nucleic acid detection before inoculum quantity can be incorporated into the above vision. There is also the potential of exploring other approaches (e.g., hyper spectral, volatiles [Ghaffari et al. 2010; Martinelli et al. 2014]) for specific detection of disease development.

\section{ACKNOWLEDGMENTS}

This work was supported by American Vineyard Foundation, National Science Foundation (AGS-1255662), Oregon Wine Board, Viticulture Consortium West, University of Utah, and USDA-ARS CRIS 5358-22000-0390-OOD. We thank T. Neill, L. Thiessen, A. Peetz, D. Martin, J. Keune, and D. Gent for discussion and refining our ideas on molecular detection and quantification and E. Pardyjak, N. Miller, B. Baily, and T. Price for their insight into turbulent flows and particle dispersion. The use of trade, firm, or corporation names in this publication is for the information and convenience of the reader. Such use does not constitute an official endorsement or approval by the United States Department of Agriculture or the Agricultural Research Service of any product or service to the exclusion of others that may be suitable. 


\section{LITERATURE CITED}

Austin, C. N., and Wilcox, W. F. 2012. Effects of sunlight exposure on grapevine powdery mildew development. Phytopathology 102:857-866.

Aylor, D. E. 1975. Force required to detach conidia of Helminthosporium maydis. Plant Physiol. 55:99-101.

Aylor, D. E. 1989. Temporal and spatial development of bean rust epidermis initiated from an inoculated line source. Phytopathology 79:146-151.

Aylor, D. E. 1990. The role of intermittent wind in the dispersal of fungal pathogens. Annu. Rev. Phytopathol. 28:73-92.

Aylor, D. E. 2003. Spread of plant disease on a continental scale: Role of aerial dispersal of pathogens. Ecology 84:1989-1997.

Aylor, D. E., and Flesch, T. K. 2001. Estimating spore release rates using a Lagrangian stochastic simulation model. J. Appl. Meteorol. 40:1196-1208.

Aylor, D. E., Schmale, D. G., Shields, E. J., Newcomb, M., and Nappo, C. J. 2011. Tracking the potato late blight pathogen in the atmosphere using unmanned aerial vehicles and Lagrangian modeling. Agric. For. Meteorol. $151: 251-260$.

Aylor, D. E., and Sutton, T. B. 1992. Release of Venturia inaequalis ascospores during unsteady rain: Relationship to spore transport and deposition. Phytopathology 82:532-540.

Bailey, B. N., Overby, M., Willemsen, P., Pardyjak, E. R., Mahaffee, W. F., and Stoll, R. 2014a. A scalable plant-resolving radiative transfer model based on optimized GPU ray tracing. Agric. For. Meteorol. 198-199:192-208.

Bailey, B. N., and Stoll, R. 2013. Turbulence in sparse, organized vegetative canopies: A large-eddy simulation study. Boundary-Layer Meteorol. 147: $369-400$

Bailey, B. N., and Stoll, R. 2016. The creation and evolution of coherent structures in plant canopy flows and their role in turbulent transport. J. Fluid Mech. 789:425-460.

Bailey, B. N., Stoll, R., Pardyjak, E. R., and Mahaffee, W. F. 2014b. Effect of vegetative canopy architecture on vertical transport of massless particles. Atmos. Environ. 95:480-489.

Bailey, B. N., Stoll, R., Pardyjak, E. R., and Miller, N. E. 2016. A new threedimensional energy balance model for complex plant canopy geometries: Model development and improved validation strategies. Agric. For. Meteorol. 218-219:146-160.

Banks, D., and Meroney, R. N. 2001. The applicability of quasi-steady theory to pressure statistics beneath roof-top vortices. J. Wind Eng. Ind. Aerodyn. 89:569-598

Banks, D., Meroney, R. N., Sarkar, P. P., Zhao, Z., and Wu, F. 2000. Flow visualization of conical vortices on flat roofs with simultaneous surface pressure measurement. J. Wind Eng. Ind. Aerodyn. 84:65-85.

Bar, T., Kubista, M., and Tichopad, A. 2012. Validation of kinetics similarity in qPCR. Nucleic Acids Res. 40:1395-1406.

Baylis, A. 2014. Is precision agriculture ready to tackle pest management? Outlooks Pest Manage. 25:350-351.

Berger, R. D. 1969. A celery blight spray program based on disease forecasting. Fla. State Hortic. Soc. 42:107-111.

Bilodeau, G. J., Lévesque, C. A., de Cock, A. W. A. M., Duchaine, C., Brière, S., Uribe, P., Martin, F. N., and Hamelin, R. C. 2007. Molecular detection of Phytophthora ramorum by real-time polymerase chain reaction using TaqMan, SYBR Green, and molecular beacons. Phytopathology 97: 632-642.

Bouvet, T., Wilson, J. D., and Tuzet, A. 2006. Observations and modeling of heavy particle deposition in a windbreak flow. J. Appl. Meteorol. Climatol. 45:1332-1349.

Brewer, M. T., Frenkel, O., and Milgroom, M. G. 2012. Linkage disequilibrium and spatial aggregation of genotypes in sexually reproducing populations of Erysiphe necator. Phytopathology 102:997-1005.

Brown, J. K. M., and Hovmøller, M. S. 2002. Aerial dispersal of pathogens on the global and continental scales and its impact on plant disease. Science 297:537-541.

Bryan, N. C., Stewart, M., Granger, D., Guzik, T. G., and Christner, B. C. 2014. A method for sampling microbial aerosols using high altitude balloons. J. Microbiol. Methods 107:161-168.

Capote, N., Pastrana, A. M., Aguado, A., and Sánchez-Torres, P. 2012. Molecular tools for detection of plant pathogenic fungi and fungicide resistance. Pages 151-202 in: Plant Pathology. C. J. R. Cumagun, ed. In Tech, Rijeka, Croatia.

Carisse, O., Bacon, R., and Lefebvre, A. 2009a. Grape powdery mildew (Erysiphe necator) risk assessment based on airborne conidium concentration. Crop Prot. 28:1036-1044.

Carisse, O., McCartney, H. A., Gagnon, J. A., and Brodeur, L. 2005. Quantification of airborne inoculum as an aid in the management of leaf blight of onion caused by Botrytis squamosa. Plant Dis. 89:726-733.

Carisse, O., Savary, S., and Willocquet, L. 2008. Spatiotemporal relationships between disease development and airborne inoculum in unmanaged and managed Botrytis leaf blight epidemics. Phytopathology 98:38-44.
Carisse, O., Tremblay, D. M., Lévesque, C. A., Gindro, K., Ward, P., and Houde, A. 2009b. Development of a TaqMan real-time PCR assay for quantification of airborne conidia of Botrytis squamosa and management of Botrytis leaf blight of onion. Phytopathology 99:1273-1280.

Carroll, J. E., and Wilcox, W. F. 2003. Effects of humidity on the development of grapevine powdery mildew. Phytopathology 93:1137-1144.

Chamecki, M. 2013. Persistence of velocity fluctuations in non-Gaussian turbulence within and above plant canopies. Phys. Fluids 25:115110.

Chandelier, A., Helson, M., Dvorak, M., and Gischer, F. 2014. Detection and quantification of airborne inoculum of Hymenoscyphus pseudoalbidus using real-time PCR assays. Plant Pathol. 63:1296-1305.

Chen, T., and Romesberg, F. E. 2014. Directed polymerase evolution. FEBS Lett. 588:219-229.

Chesson, P., and Lee, C. T. 2005. Families of discrete kernels for modeling dispersal. Theor. Popul. Biol. 67:241-256.

Dahlberg, K. R., and Vanetten, J. L. 1982. Physiology and biochemistry of fungal sporulation. Annu. Rev. Phytopathol. 20:281-301.

David, R. 2014. Voices of Ancient Egypt: Contemporary Accounts of Daily Life. ABC-CLIO Greenwood, Santa Barbara, CA.

Davis, J. M., Eisner, A. D., Wiener, R. W., and Main, C. E. 1997. A flow visualization study of spore release using a wind tunnel-mounted laser light sheet. Plant Dis. 81:1057-1065.

De Boer, S. H., and López, M. M. 2012. New grower-friendly methods for plant pathogen monitoring. Annu. Rev. Phytopathol. 50:197-218.

Delp, B. R., Stowell, L. J., and Marois, J. J. 1986. Evaluation of field sampling techniques for estimation of disease incidence. Phytopathology 76:1299-1305.

Demeke, T., and Jenkins, G. R. 2010. Influence of DNA extraction methods, PCR inhibitors and quantification methods on real-time PCR assay of biotechnology-derived traits. Anal. Bioanal. Chem. 396:1977-1990.

Dial, R. J., Nadkarni, N. M., and Jewell, C. D. 2011. Canopy structure in a 650-year Douglas-fir chronosequence in western Washington: Distribution of canopy elements and open space. For. Sci. 57:309-319.

Draxler, R. R., and Hess, G. D. 1997. Description of the HYSPLIt_4 modeling system. NOAA Technical Memorandum ERL ARL-224. Air Resources Laboratory, Silver Spring, MD

Eninger, R. M., and Johnson, R. L. 2015. Unmanned aerial systems in occupational hygiene-learning from allied disciplines. Ann. Occup. Hyg. 59: 949-958.

Falacy, J. S., Grove, G. G., Mahaffee, W. F., Galloway, H., Glawe, D. A., Larsen, R. C., and Vandemark, G. J. 2007. Detection of Erysiphe necator in air samples using the polymerase chain reaction and species-specific primers. Phytopathology 97:1290-1297.

Ferrandino, F. J. 1993. Dispersive epidemic waves: I. Focus expansion within a linear planting. Phytopathology 83:795-802.

Ferrandino, F. J. 2012. Time scales of inoculum production and the dynamics of the epidemic. Phytopathology 102:728-732.

Ferrandino, F. J., and Aylor, D. E. 1987. Relative abundances and deposition gradients of clusters of urediniospores of Uromyces phaseoli. Phytopathology 77:107-111.

Ferro, D. N., and Southwick, E. E. 1984. Microclimates of small arthropods: Estimating humidity within the leaf boundary layer. Environ. Entomol. 13: 926-929.

Fowler, W. W. 1899. The Roman Festivals of the Period of the Republic: An Introduction to the Study of the Religion of the Romans. The Macmillan Company. New York.

Fraaije, B. A., Cools, H. J., Fountaine, J., Lovell, D. J., Motteram, J., West, J. S., and Lucas, J. A. 2005. Role of ascospores in further spread of QoIresistant cytochrome b alleles (G143A) in field populations of Mycosphaerella graminicola. Phytopathology 95:933-941.

Gadoury, D. M., Cadle-davidson, L., Wilcox, W. F., Dry, I. B., Seem, R. C., and Milgroom, M. G. 2012. Pathogen profile grapevine powdery mildew (Erysiphe necator): A fascinating system for the study of the biology, ecology and epidemiology of an obligate biotroph. Mol. Plant Pathol. 13:1-16.

Gent, D. H., Nelson, M. E., Farnsworth, J. L., and Grove, G. G. 2009. PCR detection of Pseudoperonospora humuli in air samples from hop yards. Plant Pathol. 58:1081-1091.

Gent, D. H., Turechek, W. W., and Mahaffee, W. F. 2007. Sequential sampling for estimation and classification of the incidence of hop powdery mildew. I: Leaf sampling. Plant Dis. 91:1002-1012.

Gent, D. H., Turechek, W. W., and Mahaffee, W. F. 2008. Spatial and temporal stability of the estimated parameters of the binary power law. Phytopathology 98:1107-1117.

Gevertz, J. L., Dunn, S. M., and Roth, C. M. 2005. Mathematical model of real-time PCR kinetics. Biotechnol. Bioeng. 92:346-355.

Ghaffari, R., Zhang, F., Iliescu, D., Hines, E., Leeson, M., Napier, R., and Clarkson, J. 2010. Early detection of diseases in tomato crops: An electronic nose and intelligent systems approach. Pages 1-6 in: Neural Networks (IJCNN), The 2010 International Joint Conference. IEEE, Barcelona. 
Gil, E., Arno, J., Llorens, J., Sanz, R., Llop, J., Rosell-Polo, J. R., Gallart, M., and Escola, A. 2014. Advanced technologies for the improvement of spray application techniques in Spanish viticulture: An overview. Sensors 14: 691-708.

Glawe, D. A. 2008. The powdery mildews: A review of the world's most familiar (yet poorly known) plant pathogens. Annu. Rev. Phytopathol. 46: 27-51.

Gregory, P. H. 1973. The Microbiology of the Atmosphere. 2nd ed. John Wiley and Sons, Inc., New York.

Gregory, P. H., and Stedman, O. J. 1953. Deposition of air-borne Lycopodium spores on plane surfaces. Ann. Appl. Biol. 40:651-674.

Harrison, M. D., Livingston, C. H., and Oshima, N. 1965. Control of potato early blight in Colorado. II. Spore traps as a guide for initiating applications of fungicides. Am. Potato J. 42:333-340.

HeeBel, N. P. 2011. Evil against evil: The demon Pazuzu. Studi Materiali Stor. Relgioni 77:357-368.

Hirst, J. M. 1959. Spore liberation and dispersal. Pages 529-538 in: Plant Pathology: Problems and Progress 1908-1958. C. S. Holton, G. W. Fisher, R. W. Fulton, H. Hart, and S. E. A. McCallan, eds. The University of Wisconsin, Madison, WI

Hirst, J. M., Stedman, O. J., and Hogg, W. H. 1967. Long-distance spore transport: Methods of measurement, vertical spore profiles and the detection of immigrant spores. J. Gen. Microbiol. 48:329-355.

Holmes, H. A., Pardyjak, E. R., Tyler, B. J., and Peterson, R. E. 2009. Investigation of the time evolved spatial distribution of urban PM2.5 concentrations and aerosol composition during episodic high PM events in Yuma, AZ. Atmos. Environ. 43:4348-4358.

Hospodsky, D., Yamamoto, N., and Peccia, J. 2010. Accuracy, precision, and method detection limits of quantitative PCR for airborne bacteria and fungi. Appl. Environ. Microbiol. 76:7004-7012.

Huffman, J. A., Prenni, A. J., DeMott, P. J., Pöhlker, C., Mason, R. H., Robinson, N. H., Fröhlich-Nowoisky, J., Tobo, Y., Després, V. R., Garcia, E., Gochis, D. J., Harris, E., Müller-Germann, I., Ruzene, C., Schmer, B., Sinha, B., Day, D. A., Andreae, M. O., Jimenez, J. L., Gallagher, M., Kreidenweis, S. M., Bertram, A. K., and Pöschl, U. 2013. High concentrations of biological aerosol particles and ice nuclei during and after rain. Atmos. Chem. Phys. 13:6151-6164.

Isard, S., and Chamecki, M. 2016. A physically based theoretical model of spore deposition for predicting spread of plant diseases. Phytopathology 106:244-253.

Isard, S. A., Gage, S. H., Comtois, P., and Russo, J. M. 2005. Principles of the atmospheric pathway for invasive species applied to soybean rust. BioScience 55:851-861.

Jackson, S. L., and Bayliss, K. L. 2011. Spore traps need improvement to fulfil plant biosecurity requirements. Plant Pathol. 60:801-810.

Jarosz, N., Loubet, B., Durand, B., McCartney, A., Foueillassar, X., and Huber, L. 2003. Field measurements of airborne concentration and deposition rate of maize pollen. Agric. For. Meteorol. 119:37-51.

Jung, W., Han, J., Choi, J.-W., and Ahn, C. H. 2015. Point-of-care testing (POCT) diagnostic systems using microfluidic lab-on-a-chip technologies. Microelectron. Eng. 132:46-57.

Klosterman, S. J., Anchieta, A., McRoberts, N., Koike, S. T., Subbarao, K. V., Voglmayr, H., Choi, Y. J., Thines, M., and Martin, F. N. 2014. Coupling spore traps and quantitative PCR assays for detection of the downy mildew pathogens of spinach (Peronospora effusa) and beet (P. schachtii). Phytopathology 104:1349-1359.

Kremheller, H. T., and Diercks, R. 1983. Epidemiologie und Prognose des Falschen Mehltaues (Pseudoperonospora humuli) an Hopfen. Z. Pflanzenkr. Pflanzenschutz 90:599-616.

Lafleur, J. P., Jonsson, A., Senkbeil, S., and Kutter, J. P. 2016. Recent advances in lab-on-a-chip for biosensing applications. Biosens. Bioelectron. 76:213-233

Laing, A., and Evans, J.-L. 2011. Introduction to Tropical Meteorology. 2nd ed. University Corporation for Atmospheric Research, Boulder, CO.

LaMondia, J. A., and Aylor, D. E. 2001. Epidemiology and management of a periodically introduced pathogen. Biol. Invasions 3:273-282.

Lucretius. 1949. De Rerum Natura. Page 887 in: De Rerum Natura: The Latin Text of Lucretius. S. B. S. William Ellery Leonard, ed. The University of Wisconsin Press, Madison, WI.

Luo, Y., Ma, Z., Reyes, H. C., Morgan, D., and Michailides, T. J. 2007. Quantification of airborne spores of Monilinia fructicola in stone fruit orchards of California using real-time PCR. Eur. J. Plant Pathol. 118:145-154.

Mack, C. A. 2011. Fifty Years Moore's Law. IEEE Transactions on Semiconductor Manufacturing. 24:202-207.

Madden, L. V., and Hughes, G. 1999. Sampling for plant disease incidence. Phytopathology 89:1088-1103.

Mahaffee, W. F. 2014. Use of airborne inoculum detection for disease management decisions. Pages 39-54 in: Detection and Diagnostics of Plant Pathogens. M. L. G. P. J. M. Bonants, ed. Springer, Dordrecht, the Netherlands.
Mahaffee, W. F., Turechek, W. W., and Ocamb, C. M. 2003. Effect of variable temperature on infection severity of Podosphaera macularis on hops. Phytopathology 93:1587-1592.

Maldonado-Ramirez, S. L., Schmale, D. G., Shields, E. J., and Bergstrom, G. C. 2005. The relative abundance of viable spores of Gibberella zeae in the planetary boundary layer suggests the role of long-distance transport in regional epidemics of Fusarium head blight. Agric. For. Meteorol. 132: 20-27.

Margosian, M. L., Garrett, K. A., Hutchinson, J. M. S., and With, K. A. 2009. Connectivity of the American agricultural landscape: Assessing the national risk of crop pest and disease spread. BioScience 59:141-151.

Marple, V. A., and Liu, B. Y. H. 1974. Characteristics of laminar jet impactors. Environ. Sci. Technol. 8:648-654.

Martinelli, F., Scalenghe, R., Davino, S., Panno, S., Scuderi, G., Ruisi, P., Villa, P., Stroppiana, D., Boschetti, M., Goulart, L. R., Davis, C. E., and Dandekar, A. M. 2014. Advanced methods of plant disease detection. A review. Agron. Sustain. Dev. 35:1-25.

May, K. R., and Clifford, R. 1967. The impaction of aerosol particles on cylinders, spheres, ribbons and discs. Ann. Occup. Hyg. 10:83-95.

McCartney, H. a., Fitt, B. D. L., and Schmechel, D. 1997. Sampling bioaerosols in plant pathology. J. Aerosol Sci. 28:349-364.

Meentemeyer, R. K., Haas, S. E., and Vaclavik, T. 2012. Landscape epidemiology of emerging infectious diseases in natural and human-altered ecosystems. Annu. Rev. Phytopathol. 50:379-402.

Meredith, D. S. 1973. Significance of spore release and dispersal mechanisms in plant disease epidemiology. Annu. Rev. Phytopathol. 11:313-342.

Merry, A., Evans, K., Corkrey, R., and Wilson, S. 2013. Coincidence of maximum severity of powdery mildew on grape leaves and the carbohydrate sink-to-source transition. Plant Pathol. 62:842-850.

Miller, N. E., Stoll, R., Mahaffee, W. F., Neill, T. M., and Pardyjak, E. R. 2015. An experimental study of momentum and heavy particle transport in a trellised agricultural canopy. Agric. For. Meteorol. 211-212:100-114.

Minogue, T. D., Rachwal, P. A., Trombley Hall, A., Koehler, J. W., and Weller, S. A. 2014. Cross-institute evaluations of inhibitor-resistant PCR reagents for direct testing of aerosol and blood samples containing biological warfare agent DNA. Appl. Environ. Microbiol. 80:1322-1329.

Mora, C., Tittensor, D. P., Adl, S., Simpson, A. G., and Worm, B. 2011. How many species are there on Earth and in the ocean? PLoS Biol. 9: e1001127.

Moran, S. M., Pardyjak, E. R., and Veranth, J. M. 2013. Understanding the role of grid turbulence in enhancing PM10 deposition: Scaling the Stokes number with R $\lambda$. Phys. Fluids 25:115103.

Morris, C. E., Sands, D. C., Glaux, C., Samsatly, J., Asaad, S., Moukahel, A. R., Gonçalves, F. L. T., and Bigg, E. K. 2013. Urediospores of rust fungi are ice nucleation active at $>-10^{\circ} \mathrm{C}$ and harbor ice nucleation active bacteria. Atmos. Chem. Phys. 13:4223-4233.

Mundt, C. 2009. Importance of autoinfection to the epidemiology of polycyclic foliar disease. Phytopathology 99:1116-1120.

Mundt, C. C., Sackett, K. E., Wallace, L. D., Cowger, C., and Dudley, J. P. 2009a. Long-distance dispersal and accelerating waves of disease: Empirical relationships. Am. Nat. 173:456-466.

Mundt, C. C., Sackett, K. E., Wallace, L. R. D., Cowger, C., and Dudley, J. P. 2009b. Aerial dispersal and multiple-scale spread of epidemic disease. EcoHealth 6:546-552.

Nicholson, P., Simpson, D. R., Weston, G., Rezanoor, H. N., Lees, A. K., Parry, D. W., and Joyce, D. 1998. Detection and quantification of Fusarium culmorum and Fusarium graminearum in cereals using PCR assays. Physiol. Mol. Plant Prot. 53:17-37.

Noll, K. E. 1970. A rotary inertial impactor for sampling giant particles in the atmosphere. Atmos. Environ. 4:9-19.

Ojiambo, P. S., Gent, D. H., Quesada-Ocampo, L. M., Hausbeck, M. K., and Holmes, G. J. 2015. Epidemiology and population biology of Pseudoperonospora cubensis: A model system for management of downy mildews. Annu. Rev. Phytopathol. 53:223-246.

Olson, N. D., and Morrow, J. B. 2012. DNA extract characterization process for microbial detection methods development and validation. BMC Res. Notes 5:668

Orlob, G. B. 1973. Ancient and medieval plant pathology. PflanzenschutzNachrichten 26:65-294.

Pan, Y., Chamecki, M., Isard, S. A., and Nepf, H. M. 2015. Dispersion of particles released at the leading edge of a crop canopy. Agric. For. Meteorol. 211-212:37-47.

Pan, Y.-L. 2015. Detection and characterization of biological and other organic-carbon aerosol particles in atmosphere using fluorescence. J. Quant. Spectrosc. Radiat. Transf. 150:12-35.

Pardyjak, E. R., Speckart, S. O., Yin, F., and Veranth, J. M. 2008. Near source deposition of vehicle generated fugitive dust on vegetation and buildings: Model development and theory. Atmos. Environ. 42:6442-6452. 
Parnell, S., Gottwald, T. R., Cunniffe, N. J., Alonso Chavez, V., and van den Bosch, F. 2015. Early detection surveillance for an emerging plant pathogen: A rule of thumb to predict prevalence at first discovery. Proc. Biol. Sci. 282:20151478.

Peetz, A. B., Mahaffee, W. F., and Gent, D. H. 2009. Effect of temperature on sporulation and infectivity of Podosphaera macularis on Humulus lupulus. Plant Dis. 93:281-286.

Prussin, A. J., Li, Q., Malla, R., Ross, S. D., and Schmale, D. G. 2014. Monitoring the long-distance transport of Fusarium graminearum from field-scale sources of inoculum. Plant Dis. 98:504-511.

Prussin, A. J., Marr, L. C., Schmale, D. G., Stoll, R., and Ross, S. D. 2015. Experimental validation of a long-distance transport model for plant pathogens: Application to Fusarium graminearum. Agric. For. Meteorol. 203: 118-130.

Raupach, M. 2001. The entrapment of particles by windbreaks. Atmos. Environ. 35:3373-3383.

Reynolds, A. 2012. Incorporating sweeps and ejections into Lagrangian stochastic models of spore trajectories within plant canopy turbulence: Modeled contact distributions are. Phytopathology 102:1026-1033.

Rieux, A., Soubeyrand, S., Bonnot, F., Klein, E. K., Ngando, J. E., Mehl, A., Ravigne, V., Carlier, J., and de Lapeyre de Bellaire, L. 2014. Long-distance wind-dispersal of spores in a fungal plant pathogen: Estimation of anisotropic dispersal kernels from an extensive field experiment. PLoS One 9: e103225.

Rogers, S. L., Atkins, S. D., and West, J. S. 2009. Detection and quantification of airborne inoculum of Sclerotinia sclerotiorum using quantitative PCR. Plant Pathol. 58:324-331.

Sackett, K. E., and Mundt, C. C. 2005. The effect of dispersal gradient and pathogen life cycle components on epidemic velocity in computer simulations. Phytopathology 95:992-1000.

Sanz-Cortiella, R., Llorens-Calveras, J., Escolà, A., Arnó-Satorra, J., Ribes-Dasi, M., Masip-Vilalta, J., Camp, F., Gràcia-Aguilá, F., Solanelles-Batlle, F., Planas-DeMartí, S., Pallejà-Cabré, T., Palacin-Roca, J., Gregorio-Lopez, E., Del-Moral-Martínez, I., and Rosell-Polo, J. R. 2011. Innovative LIDAR 3D dynamic measurement system to estimate fruit-tree leaf area. Sensors 11: 5769-5791

Savage, D., Barbetti, M. J., MacLeod, W. J., Salam, M. U., and Renton, M. 2010. Timing of propagule release significantly alters the deposition area of resulting aerial dispersal. Divers. Distrib. 16:288-299.

Savage, D., Barbetti, M. J., MacLeod, W. J., Salam, M. U., and Renton, M. 2012. Mobile traps are better than stationary traps for surveillance of airborne fungal spores. Crop Prot. 36:23-30.

Scherm, H., Thomas, C. S., Garrett, K. A., and Olsen, J. M. 2014. Metaanalysis and other approaches for synthesizing structured and unstructured data in plant pathology. Annu. Rev. Phytopathol. 52:453-476.

Schmale, D. G., III, Dingus, B. R., and Reinholtz, C. 2008. Development and application of an autonomous unmanned aerial vehicle for precise aerobiological sampling above agricultural fields. J. Field Robot. 25: 133-147.

Schmale, D. G., III, and Ross, S. D. 2015. Highways in the sky: Scales of atmospheric transport of plant pathogens. Annu. Rev. Phytopathol. 53:591-611.

Schrader, C., Schielke, A., Ellerbroek, L., and Johne, R. 2012. PCR inhibitorsOccurrence, properties and removal. J. Appl. Microbiol. 113:1014-1026.
Seinfeld, J. H., and Pandis, S. N. 2006. Atmospheric Chemistry and PhysicsFrom Air Pollution to Climate Change. 2nd ed. John Wiley \& Sons, Inc., Hoboken, NJ.

Sinoquet, H., Le Roux, X., Adam, B., Ameglio, T., and Daudet, F. A. 2001. RATP: A model for simulating the spatial distribution of radiation absorption, transpiration and photosynthesis within canopies: Application to an isolated tree crown. Plant Cell Environ. 24:395-406.

Su, W., Gao, X., Jiang, L., and Qin, J. 2015. Microfluidic platform towards pointof-care diagnostics in infectious diseases. J. Chromatogr. A 1377:13-26.

Summers, C. F., Adair, N. L., Gent, D. H., McGrath, M. T., and Smart, C. D. 2015. Pseudoperonospora cubensis and P. humuli detection using speciesspecific probes and high definition melt curve analysis. Can. J. Plant Pathol. 37:315-330.

Sutton, T. B., and Jones, A. L. 1979. Analysis of factors affecting dispersal of Podosphaera leucotricha conidia. Phytopathology 69:380-383.

Svec, D., Tichopad, A., Novosadova, V., Pfaffl, M. W., and Kubista, M. 2015. How good is a PCR efficiency estimate: Recommendations for precise and robust qPCR efficiency assessments. Biomol. Detect. Quantification 3:9-16.

Thiessen, L. D., Keune, J. A., Neill, T. M., Turechek, W. W., Grove, G. G., and Mahaffee, W. F. 2016. Development of a grower-conducted inoculum detection assay for management of grape powdery mildew. Plant Pathol. 65:238-249.

Tomlinson, J. 2010. Potential of LAMP for detection of plant pathogens. CAB reviews: Perspectives in Agriculture, Veterinary Science. Nutr. Nat. Resour. $3: 1-7$.

Turechek, W. W., and Mahaffee, W. F. 2004. Spatial pattern analysis of hop powdery mildew in the Pacific Northwest: Implications for sampling. Phytopathology 94:1116-1128.

Van der Heyden, H., Lefebvre, M., Roberge, L., Brodeur, L., and Carisse, O. 2014. Spatial pattern of strawberry powdery mildew (Podosphaera aphanis) and airborne inoculum. Plant Dis. 98:43-54.

van Hout, R., Zhu, W., Luznik, L., Katz, J., Kleissl, J., and Parlange, M. B. 2007. PIV measurements in the atmospheric boundary layer within and above a mature corn canopy. Part I: Statistics and energy flux. J. Atmos. Sci. 64:2805-2824.

von Qualen, R., and Yang, X. B. 2006. Spore traps help researchers watch for soybean rust. Integr. Crop Manage. 496:41-42.

Ward, L., and Harper, S. 2012. Loop-mediated isothermal amplification for the detection of plant pathogens. Pages 161-170 in: Plant DNA Fingerprinting and Barcoding. N. Sucher, J. R. Hennell, and M. C. Carles, eds. Spinger, Totowa, NJ.

West, J. S., and Kimber, R. B. E. 2015. Innovations in air sampling to detect plant pathogens. Ann. Appl. Biol. 166:4-17.

Willocquet, L., Berud, F., Raoux, L., and Clerjeau, M. 1998. Effects of wind, relative humidity, leaf movement and colony age on dispersal of conidia of Uncinula necator, causal agent of grape powdery mildew. Plant Pathol. 47: 234-242.

Wilson, D. J. 1979. Flow patterns over flat-roofed buildings and application to exhaust stack design. ASHRAE Transactions 85:284-295.

Zarco-Tejada, P. J., González-Dugo, V., and Berni, J. A. J. 2012. Fluorescence, temperature and narrow-band indices acquired from a UAV platform for water stress detection using a micro-hyperspectral imager and a thermal camera. Remote Sens. Environ. 117:322-337. 